\title{
Contents to volume 97
}

Akintunde, B. A.: Feeding rhythm in relation to changing patterns of $\mathrm{pH}$ in the gut of Sarotherodon galilaeus (Artedi) of Lake Kainji, Nigeria

Ashton, P. J., see Robarts et al.

Biró, P. \& Vörös, L.: Relationships between phytoplankton and fish yields in Lake Balaton

Brambilla, D. J.: Seasonal variation of egg size and number in a Daphia pulex population

Breen, C. M., see Furness \& Breen

Campbell, J. M., Clark, W. J. \& Kosinski, R.: A technique for examining microspatial distribution of Cladocera associated with shallow water macrophytes

Caron, P., see Vincent et al.

Cech, Jr., J. J., Massingill, M. J. \& Stern, H.: Growth of juvenile sacramento blackfish, Orthodon microlepidotus (Ayres)

Chan, K., Wong, P. K. \& Ng, S. L.: Growth of Enteromorpha linza in sewage effluent and sewage effluent seawater mixtures

Clark, W. J., see Campbell et al.

Couté, A.: Ultrastructure d'une cyanophycée aérienne calcifiée cavernicole: Geitleria calcarea Friedmann

Date, Y., see Ohtake et al.

Davies, R. W., Linton, L. R., Parsons, W. \& Edgington, E. S.: Chemosensory detection of prey by Nephelopsis obscura (Hirudinoidea: Erpobdellidae)

Dimentman, Ch. \& Spira, J.: Predation of Artemia cysts by water-tiger larvae of the genus Anacaena (Coleoptera, Hydrophilidae)

Dudgeon, D.: An investigation into some physical and biotic effects of flooding on reservoir mud previously subjected to a period of aerial exposure

Earnshaw, R., see Willoughby \& Earnshaw

Edgington, E. S., see Davies et al.

Fernando, C. H.\& Holčík, J.: The nature of fish communities: A factor influencing the fishery potential and yields of tropical lakes and reservoirs

Flora, M. D. \& Rosendahl, P. C.: Historical changes in the conductivity and ionic characteristics of the source water for the Shark River Slough, Everglades National Park, Florida, U.S.A.

Folsom, T. C., see Manuel \& Folsom

Furness, H. D. \& Breen, C. M.: Decomposition of Cynodon dactylon (L.) Pers. in the seasonally flooded areas of the Pongolo river floodplain: pattern and significance of dry matter and nutrient loss

Godbout, L. \& Hynes, H. B. N.: The three dimensional distribution of the fauna in a single riffle in a stream in Ontario

Ham, S. F.: The Crustacea of some chalk streams in southern England

Haniffa, M. A.: Effects of feeding level and body size on food utilization of the freshwater snail Pila Globosa 
Hill, B. H. \& Webster, J. R.: Periphyton production in an Appalachian river

Holčík, J., see Fernando \& Holčík

Hynes, H. B. N., see Godbout \& Hynes

Jenkin, P. M.: Temperature, hydrochemistry and plankton in Wicken Brickpits, 1930-1931

Kikuchi, E. \& Kurihara, Y.: The effects of the oligochaete Branchiura sowerbyi Beddard (Tubificidae) on the biological and chemical characteristics of overlying water and soil in a submerged ricefield soil system

Kondo, K., see Ohtaka et al.

Kosinski, R., see Campbell et al.

Kurihara, Y., see Kikuchi \& Kurihara

Lafontaine, N., see Vincent et al.

Linton, L. R., see Davies et al.

Manuel, K. L. \& Folsom, T. C.: Instar sizes, life cycles, and food habits of five Rhyacophila (Trichoptera: R hyacophilidae) species from the Appalachian Mountains of South Carolina, U.S.A. Massingill, M. J., see Cech et al.

Misra, J. K.: Occurrence, distribution and seasonality of aquatic fungi as affected by chemical factors in six alkaline ponds of India

Myrand, B. \& Noue, J. de la: Croissance individuelle et dynamique de population de Daphnia Magna en culture dans les eaux usées traitées

$\mathrm{Ng}$, S. L., see Chan et al.

Noüe, de la, see Myrand \& de la Noüe

Ohtake, H., Kondo, K., Seike, Y.\& Date, Y.: Seasonal and areal features of the lagoonal environment in Lake Nakanoumi, a shallow coastal lagoon in Japan

Parsons, W., see Davies et al.

Robarts, R. D., Ashton, P. J., Thornton, J. A., Taussig, H. J. \& Sephton, L. M.: Overturn in a hypertrophic, warm, monomictic impoundment (Hartbeespoort Dam, South Africa)

Rosendahl, R. C., see Flora \& Rosendahl

Seike, Y., see Ohtake et al.

Selkirk, W. T.: An analysis, by bioassay, of the factors which limit algal growth in the P.K. le Roux Impoundment, Orange River, South Africa

Sephton, L. M., see Robarts et al.

Spira, J., see Dimentman \& Spira

Stern, H., see Cech et al.

Taussig, H. J., see Robarts et al.

Thornton, J. A., see Robarts et al.

Vincent, B., Lafontaine, N. \& Caron, P.: Facteurs influencant la structure des groupements de macroinvertébrés benthiques et phytophiles dans la zone littorale du Saint-Laurent (Québec)

Vörös, L., see Biró \& Vörös

Weaks, T. E.: A step-wise discriminant analysis of the effects of long term coal mine drainage and coal dredging on phytoplankton of the Guyandotte River

Webster, J. R., see Hill \& Webster

Willoughby, L. G. \& Earnshaw, R.: Gut passage times in Gammarus pulex (Crustacea, Amphipoda) and aspects of summer feeding in a stony stream

Wong, P.K., see Chan et al. 